\author{
Izabela Kapera \\ Akademia Wychowania Fizycznego w Krakowie \\ Wydział Turystyki i Rekreacji \\ Katedra Turystyki i Rekreacji \\ lowczowska@poczta.onet.pl
}

\title{
MOTYWY WYBORU I OCZEKIWANIA STUDENTÓW Z UKRAINY WOBEC KSZTAŁCENIA NA KIERUNKACH ZWIAZZANYCH Z TURYSTYKA
}

\begin{abstract}
Abstrakt: Celem badań była analiza motywów wyboru oraz identyfikacji oczekiwań studentów z Ukrainy wobec kształcenia na kierunkach z zakresu turystyki. W postępowaniu badawczym wykorzystano kwestionariusz ankiety skierowany do wymienionej grupy osób. Wykazano, że głównym motywem wyboru studiów w Polsce była w $60 \%$ chęć jednoczesnego studiowania i podjęcia pracy. Niemal połowa respondentów po ukończeniu studiów zamierza zostać w Polsce. Młodzi ludzie, którzy wyrazili chęć wyjazdu do innych krajów najczęściej wskazywali Hiszpanię i Niemcy. Jednocześnie większość osób po skończeniu studiów chciałaby pracować w zawodach związanych z turystyką, najczęściej w biurach podróży i hotelach.
\end{abstract}

Słowa kluczowe: turystyka, kształcenie, studenci zagraniczni, Ukraina.

\section{WSTĘP}

Obecna sytuacja demograficzna sprawia, że uczelnie polskie zabiegają o pozyskanie studentów zagranicznych. Do innych czynników, które przyczyniają się do wzrostu liczby studentów zagranicznych należą: globalizacja czy internacjonalizacja szkolnictwa wyższego na świecie, latwiejszy przepływ studentów, uruchomienie europejskich programów edukacyjnych, zmiana nastawienia rządów, które upatrują $\mathrm{w}$ zjawisku szansę na rozwój gospodarczy i władz uczelni, dostrzegających szansę na podniesienie prestiżu placówki (DŁUGOSZ 2015). W związku z tym ważne jest zdobycie informacji na temat oczekiwań młodych ludzi przyjeżdżających na studia w Polsce.

Według stanu na 30.11.2016 r. w Polsce studiowało 1348822 osób, w tym 65793 cudzoziemców (GUS 2017). Ponad połowa wszystkich studiujących w naszym kraju cudzoziemców to studenci z Ukrainy (35 584 osób) (GUS 2017). Wśród kierunków często wybieranych przez młodzież są również związane z turystyką.

Celem badań autorki była analiza motywów wyboru oraz identyfikacji oczekiwań młodych ludzi z Ukrainy wobec kształcenia na kierunkach z zakresu turystyki. Zagadnienia dotyczące ukraińskich studentów i ich kształcenia w Polsce są coraz częściej podejmowane w literaturze (BERGIER, BERGIER, TsOs 2012, DŁUGOSZ 2015, GIERKO 2015, GÓRSKA 2015, BIERÓWKA 2016, GAWRON 2016, LEŚNIAK 2016, WOJTULEWSKI 2016), niemniej jednak brak jest analiz tego typu $\mathrm{w}$ odniesieniu do kształcenia na kierunkach związanych $\mathrm{z}$ turystyką.

Artykuł niniejszy podzielono na trzy części dotyczące: zagadnienia studentów zagranicznych w Polsce, prezentacji metodologii i wyników badań opartych na kwestionariuszu ankietowym skierowanym do młodych ludzi uczących się w Polsce oraz omówienia wyników badań na tle literatury przedmiotu (dyskusja).

\section{STUDENCI ZAGRANICZNI W POLSCE}

W ostatnich latach znacząco wzrasta liczba cudzoziemców studiujących w Polsce. W roku akad. 1995/1996 studiowało w Polsce nieco więcej niż 5 tys. osób z zagranicy, 10 lat później było ich drugie tyle, a po kolejnym 10-leciu liczba ta sięgnęła ponad 57 tys. (tab. 1). 
Tab. 1. Cudzoziemcy w szkołach wyższych w Polsce w latach akademickich 1995/1996-2015/2016

\begin{tabular}{|l|c|}
\hline $\begin{array}{c}\text { Rok } \\
\text { akademicki }\end{array}$ & $\begin{array}{c}\text { Liczba cudzoziemców w szkołach } \\
\text { wyższych }\end{array}$ \\
\hline $1995 / 1996$ & 5202 \\
\hline $2000 / 2001$ & 6563 \\
\hline $2001 / 2002$ & 7380 \\
\hline $2002 / 2003$ & 7608 \\
\hline $2003 / 2004$ & 8106 \\
\hline $2005 / 2006$ & 10092 \\
\hline $2006 / 2007$ & 11753 \\
\hline $2007 / 2008$ & 13695 \\
\hline $2008 / 2009$ & 15862 \\
\hline $2009 / 2010$ & 17000 \\
\hline $2010 / 2011$ & 21474 \\
\hline $2011 / 2012$ & 24253 \\
\hline $2012 / 2013$ & 29172 \\
\hline $2013 / 2014$ & 35983 \\
\hline $2014 / 2015$ & 46101 \\
\hline $2015 / 2016$ & 57119 \\
\hline
\end{tabular}

Źródło: opracowanie na podstawie GUS (2016, s. 35).

Najwięcej obcokrajowców uczy się w Warszawie, Krakowie, Lublinie i we Wrocławiu. W roku akademickim 2015/2016 - jak już wspomniano - w Polsce studiowało ponad 57 tys. osób z zagranicy (głównie z państw europejskich). W grupie 10 państw, z których najliczniej przybywają młodzi ludzie na studia znalazły się: Ukraina, Białoruś, Norwegia, Hiszpania, Szwecja, Turcja, Czechy, Rosja, Niemcy i Litwa. Ogółem do Polski przyjeżdżają studiować przedstawiciele z więcej niż 150 krajów. Ponad połowę wszystkich studentów zagranicznych $\mathrm{w}$ naszym kraju stanowia Ukraińcy. Jednocześnie nacja ta jest w Polsce najliczniejszą grupą obywateli państw trzecich (52 003, tj. 42\%) (ŁYSIENIA, red. 2015). Jest to także grupa o największej dynamice wzrostu liczby studentów w naszym kraju. W roku 1998 z Ukrainy pochodziło 868 studiujących w Polsce, a w 2003 liczba ta zwiększyła się o ponad 1000 (KORCZYŃSKA, KAŹMIERKIEWICZ 2005). W kolejnych latach notowano dalszy dynamiczny jej wzrost (tab. 2).

Tab. 2. Studenci z Ukrainy w Polsce w latach akademickich 2005/2006-2014/2015

\begin{tabular}{|l|c|}
\hline Rok akademicki & Liczba studentów z Ukrainy \\
\hline $2005 / 2006$ & 1980 \\
\hline $2006 / 2007$ & 2223 \\
\hline $2007 / 2008$ & 2467 \\
\hline $2008 / 2009$ & 2831 \\
\hline $2009 / 2010$ & 3499 \\
\hline $2010 / 2011$ & 4879 \\
\hline $2011 / 2012$ & 6321 \\
\hline $2012 / 2013$ & 9747 \\
\hline $2013 / 2014$ & 15123 \\
\hline $2014 / 2015$ & 23329 \\
\hline
\end{tabular}

Źródło: opracowanie na podstawie: V. GIERKO (2015).
Duża liczba studentów z Ukrainy na polskich uczelniach przynosi zysk ekonomiczny zarówno szkołom, jak i miastom, w których kształcą się i mieszkają, wpływa na współczynnik poziomu umiędzynarodowienia kształcenia, na unowocześnienie ofert polskich uczelni i dostosowania ich do potrzeb zainteresowanych cudzoziemców oraz jest przynajmniej częściowym remedium na radzenie sobie przez uczelnie z konsekwencjami niżu demograficznego (GIERKO 2015). Sytuacja zwiększającej się liczby studentów z zagranicy niewątpliwie przynosi korzyści uczelniom w kraju, ale bywa także tematem budzącym głosy krytyki w różnych środowiskach. Na łamach czasopism naukowych w ostatnich latach zagościło określenie „ukrainizacja” polskich uczelni (GIERKO 2015). Trudno też nie wspomnieć o opiniach wyrażających niezadowolenie $\mathrm{z}$ powodu napływu kolegów z Ukrainy do Polski (http://lublin.wyborcza.pl), a także o przypadkach pobicia $\mathrm{w}$ związku z przynależnością narodową (Podejrzani o pobicie... 2017).

Wizerunek Ukraińców wyłaniający się ze stron wybranej polskiej prasy szczegółowo analizował D. BARAN (2016), który zauważył, że sposób prezentowania migrantów w środkach przekazu ma bezpośrednie przełożenie na odbiór społeczny (BARAN 2016). Badania CBOS wskazują, że co czwarty Polak ma pozytywne nastawienie do Ukraińców, 34\% niechętne, a 33\% obojętne (CBOS 2016). Na zbliżonym poziomie kształtuje się sympatia do Bułgarów, Chińczyków, Białorusinów (CBOS 2016). Do najbardziej lubianych narodów przez Polaków należą Czesi, Włosi i Słowacy, których sympatią darzy około połowa rodaków (CBOS 2016). W tab. 3 przedstawiono sympatie $i$ antypatie Polaków do Ukraińców na tle wybranych narodów.

Tab. 3. Nastawienie Polaków wobec innych narodów

\begin{tabular}{|l|c|c|c|c|}
\hline \multirow{2}{*}{ Naród } & \multicolumn{4}{|c|}{$\begin{array}{c}\text { Jakby Pan(i) określił(a) swój stosunek do innych } \\
\text { narodów (\%) }\end{array}$} \\
\cline { 2 - 5 } & sympatia & obojętność & niechęć & $\begin{array}{c}\text { trudno } \\
\text { powiedzieć }\end{array}$ \\
\hline Czesi & 50 & 30 & 13 & 7 \\
\hline Ukraina & 27 & 33 & 34 & 6 \\
\hline Arabowie & 8 & 16 & 67 & 9 \\
\hline
\end{tabular}

Źródło: opracowanie na podstawie: CBOS (2016, s. 3).

Dla porównania, z badań przeprowadzonych wśród studentów krakowskich uczelni wynika, że polscy studenci (45\%) charakteryzują się pozytywnym nastawieniem wobec swoich ukrainskich kolegów, $28 \% \mathrm{z}$ nich prezentuje postawę ambiwalentną, a negatywną bądź skrajnie negatywną 24\% (WOJTULEWSKI 2016). 


\section{WYNIKI BADAŃ}

Badania pilotażowe przeprowadzono w marcu i kwietniu 2017 r. w Krakowie. Narzędzie badawcze stanowił kwestionariusz ankiety skierowany do studentów z Ukrainy studiujących na kierunku ,turystyka i rekreacja" lub na specjalności związanej z turystyką. W badaniu wzięło udział 100 respondentów, w tym 80 kobiet i 20 mężczyzn w wieku od 18 do 28 lat. Główne pytania badawcze dotyczyły motywów wyboru studiów w Polsce na kierunkach związanych z turystyką i planów co do zatrudnienia po studiach. O wyborze Krakowa jako miejsca badań zdecydowała wysoka ranga ośrodka, duży w nim ruch turystyczny i fakt, że należy do grupy najczęściej wybieranych miast w Polsce przez studentów zagranicznych.

W pierwszym pytaniu respondenci zostali zapytani o główne motywy przyjazdu do Polski. $60 \%$ badanych odpowiedziało, że przyjechali do Polski, by jednocześnie studiować i pracować. Wyłącznie na studia przybyło 36\% osób. Czterech respondentów wskazywało inny powód (np. udział w projekcie).

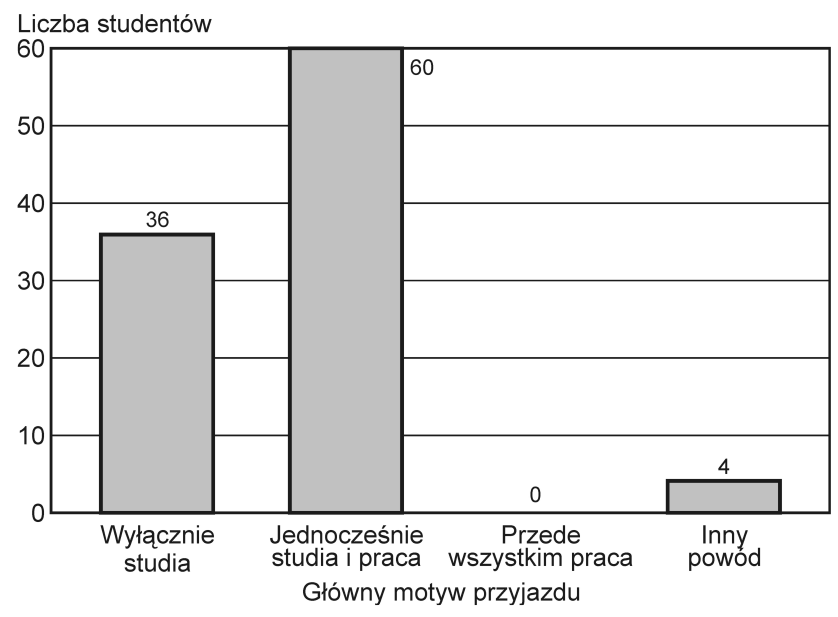

Rys. 1. Główne motywy przyjazdu Ukraińców na studia do Polski $(N=100)$

Źródło: opracowanie własne

Uszczegółowieniem zagadnień związanych z powodami wyboru studiów w Polsce było pytanie drugie. Respondenci mieli możliwość wskazania dowolnej liczby odpowiedzi spośród 14 wariantów (włącznie z opcją „inne”). Najwięcej osób - 86 (86\%) wskazało, że kierowała nimi chęć uzyskania dyplomu zagranicznej uczelni. Nieco mniej ankietowanych, bowiem 82 (82\%), chciało poznać świat, nowe miejsca. 74 osoby wyraziły przekonanie o lepszych możliwościach znalezienia pracy i zrobienia kariery, a 60 odpowiedzi $(60 \%)$ związanych było z możliwością życia na wyższym poziomie (rys. 2).

Zadowolenie ze studiów w Polsce wyraziło 89 osób (89\%), a 11 (11\%) miało zdanie przeciwne.

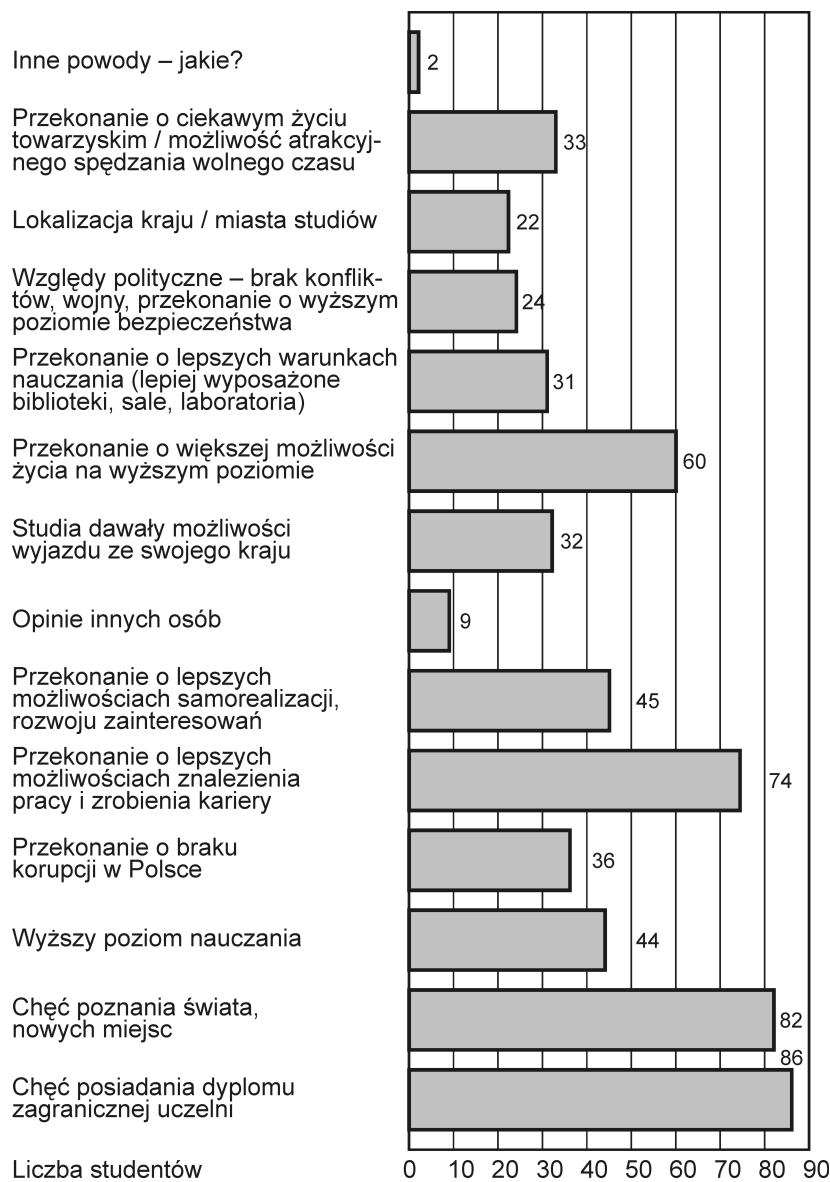

Rys. 2. Szczegółowe powody, które zadecydowały o wyborze studiów w Polsce Źródło: opracowanie własne

W dalszej części badania zapytano o powody wyboru studiów w zakresie turystyki. Większość odpowiadała, że turystyka im się podoba („podoba mi się”, "lubię to" lub „interesuję się tym”) - nie precyzując, czy chodzi o kierunek studiów, czy o to, że lubią podróżować. Część respondentów wybierając kierunek zwracała uwagę na kwestie związane z przyszłą pracą i z chęcią podróżowania. Sporadycznie pojawiały się też inne odpowiedzi, np.: „,bo nie lubię matematyki”. Studenci zostali także poproszeni o wskazanie plusów i minusów studiowania w Polsce. W grupie pozytywów przeważały takie odpowiedzi, jak: dyplom zagranicznej uczelni, wyższy poziom nauczania w Polsce, brak korupcji, możliwość wyjazdu ze swojego kraju, co łączy się z kolejną odpowiedzią - możliwością podróżowania w strefie Shengen/Europie/UE, znalezienie pracy w Polsce. Do minusów respondenci zaliczyli przede wszystkim: płatne studia, zbyt mało wycieczek/zajęć w terenie i zajęć praktycznych, sporą odległość od domu, a także: zbyt wielu Ukraińców, trudny proces załatwiania dokumentów i kart pobytu. Ogólnie rzecz ujmując, studenci zza wschodniej gra- 
nicy chcieliby, aby było taniej, aby było mniej Ukraińców, ale więcej zajęć praktycznych.

Aż 81\% ankietowanych studiując w Polsce podejmowało pracę, a 19\% nie pracowało. W 58 (58\%) przypadkach była to branża związana z turystyką. Młodzi ludzie pracowali głównie w obiektach bazy gastronomicznej (35 osób) i noclegowych (31 badanych) (rys. 3).

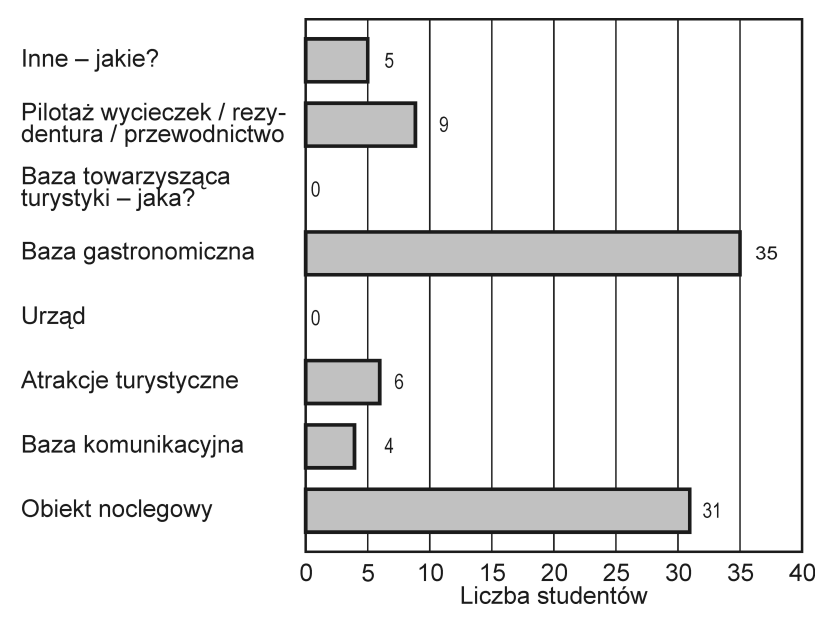

Rys. 3. Miejsce pracy w Polsce ukraińskich studentów (dotyczy obiektów/miejsc związanych z branżą turystyczną) Źródło: opracowanie własne

Blisko połowa respondentów (46 osób) zamierza po ukończeniu studiów zostać w Polsce, 43 (43\%) ankietowanych jeszcze nie wie, czy chce w naszym kraju mieszkać po studiach, a $11(11 \%)$ osób nie wyraziło chęci pozostania w Polsce. Generalnie do swojego kraju nie chce wracać ponad $72 \%$ młodych ludzi. $24 \%$ jeszcze nie podjęło decyzji w tej kwestii. Tylko cztery osoby zamierzają powrócić do państwa, z którego pochodzą. 34 respondentów chce wyjechać do innego kraju, ale zdecydowana większość jeszcze nie wie co zrobi po studiach. Ukraińcy, którzy wyrazili chęć wyjazdu do innych krajów, najczęściej wymieniali po kilka państw, w tym Hiszpanię (19 razy) i Niemcy (18), a dalej: USA (13), Włochy (12), Wielką Brytanię (7), Francję/Austrię/Norwegię (po 4), Szwecję/Holandię/Japonię (po 3), Szwajcarię oraz Brazylię/Greccję (po 2), ale także podano raz Czechy i raz Kanadę.

Większość ankietowanych - 72, po skończeniu studiów chciałaby pracować w zawodach związanych z turystyką, siedem osób nie zamierza szukać zatrudnienia w tej branży, 20 respondentów jeszcze nie wie, gdzie byliby skłonni pracować, a jedna osoba nie udzieliła odpowiedzi. Spośród miejsc, w których oczekiwaliby znaleźć zatrudnienie najczęściej wymieniane były biura podróży i hotele. Pojawiały się też odpowiedzi związane z gastronomią, pilotażem/przewodnictwem i rezydentura, centrami kongresowymi oraz ze statkiem pasażerskim. Kilka osób pragnie prowadzić swój własny biznes związany z turystyką.
Studenci ukraińscy w większości chcieliby uzyskiwać zarobki w przedziale 3000-5000 zł.

Nadmienić należy, że 89\% respondentów poleciłoby studiowanie $\mathrm{w}$ Polsce, 10 respondentów nie zarekomenduje Polski na studia, a jedna osoba nie udzieliła odpowiedzi.

\section{DYSKUSJA I PODSUMOWANIE}

Z przeprowadzonych badań wynika, że młodzi ludzie z Ukrainy najczęściej podejmowali decyzję o nauce w Polsce w związku z chęcią połączenia studiów i pracy. Spostrzeżenia te $\mathrm{w}$ dużej mierze są zbieżne $\mathrm{z}$ wynikami analiz przeprowadzonych przez GUS (2016), zgodnie z którymi ponad połowa ukrainskich studentów (57\%) zadeklarowała, że przyjechała do Polski z zamiarem jednoczesnego studiowania i podjęcia pracy - w przypadku prezentowanych na lamach artykułu danych było to $60 \%$. Według badan I. CHMIELEWSKIEJ, G. DOBROCZEK i J. PUZYNKIEWICZ (2016), połowa studentów z Ukrainy poza studiowaniem jest aktywna na rynku pracy, a duża część zgłasza chęć podjęcia pracy.

Dalsze szczegółowe odpowiedzi na pytania zawarte w kwestionariuszu wskazywały, że zależy im przede wszystkim na zdobyciu dyplomu zagranicznej uczelni. Potwierdzają to badania przeprowadzone na Podkarpaciu wśród studentów ukraińskich, które wskazują, że głównym motywem była chęć zdobycia dyplomu zagranicznej uczelni i poznanie świata (DŁUGOSZ 2015). Większość studentów podjęła pracę w Polsce, przy czym z badań wynika, ze respondenci chętnie pracowali w zawodach związanych z kierunkiem/ specjalizacją, czyli byli aktywni zawodowo w branży turystycznej. Nadmienić należy, że w 2015 r. wydano cudzoziemcom w Polsce 65000 zezwoleń na pracę, z czego ponad 50000 obywatelom Ukrainy (ŁYSIENIA 2015).

Jak wskazują przywoływane już analizy GUS (2016), ukraińscy studenci najczęściej znajdowali pracę w usługach związanych $z$ handlem 26,3\%, w hotelarstwie i gastronomii - 20\%, lub w innych usługach - 11,6\% (GUS 2016).

Przeprowadzone przez autorkę badania dowodzą, że młodzi ludzie z Ukrainy po ukończeniu studiów chcieliby pracować w zawodach związanych $\mathrm{z}$ turystyką - głównie w biurach podróży i obiektach noclegowych oraz że marzą o zarobkach na poziomie między 3000 a 5000 zł. Tymczasem obecnie średnia zarobków studentów z Ukrainy wynosi 1526 zł (GUS 2016). Dla porównania, badania R. TRZCIŃSKIEGO (2015) wskazują, że zarobki, jakie chcieliby oni osiągnąć w rok po ukończeniu uczelni (średnia kwota netto wyliczona $z$ odpowiedzi wszystkich studentów, bez 
względu na plany zawodowe) to kwota 4155 zł (TRZCIŃSKI 2015).

W kwestionariuszu zapytano także respondentów o chęć pozostania w Polsce po studiach. 46 osób odpowiedziało, że chciałoby tu zostać. Dane GUS (2016) wskazują na 36,6\% chętnych na życie w Polsce i 32,5\% wyrażających zamiar częściowego związku z Polską. Ci ze studentów, którzy rozważają wyjazd do innego kraju najchętniej wybierali Hiszpanię, Niemcy, USA, Włochy, Wielką Brytanię. Podobny zestaw krajów (USA, Niemcy, Anglia, Czechy) wskazanych jako następny etap ich życia pojawiał się w analizach P. DŁUGOSZA (2015).

Zdecydowana większość młodych ludzi poleciłaby studiowanie w Polsce. R. TRZCIŃSKI (2015) potwierdza w swoich analizach zadowolenie obcokrajowców ze studiów w Polsce. Autor stwierdził, że studenci $z$ innych krajów na ogół dobrze oceniają poziom nauczania w Polsce, a w skali od 1 do 8 ocenili zadowolenie ze studiów na poziomie 6,1 (TRZCIŃSKI 2015). Wśród plusów studiowania w Polsce respondenci wymieniali głównie możliwość zdobycia dyplomu zagranicznej uczelni. Minusy dotyczyły przede wszystkim odpłatności za studia.

Co ciekawe, cudzoziemcy nie zgłaszali problemów językowych. Na zagadnienie to zwróciła uwage A. GÓRSKA (2015), która podkreśliła, że młodzi ludzie z Ukrainy twierdzą, że znają język polski, mimo że ich aktywna znajomość języka jest bardzo słaba, a wypowiedzi zawierają liczne słowa i formy obce dla języka polskiego. Aż 75\% studentów w badaniach autorki oceniło znajomość naszego języka jako dobrą lub bardzo dobrą (GÓRSKA 2015).

W podsumowaniu analizowanego na podstawie 100 ankiet zagadnienia motywów studiowania i oczekiwań młodzieży ukraińskiej w Polsce należy zaznaczyć, że prezentowane na łamach niniejszego artykułu badania mają charakter pilotażowy i odnoszą się do studentów uczących się w Krakowie. W celu dogłębnego zbadania zjawiska pożądane jest przeprowadzenie podobnych analiz w innych ośrodkach akademickich na terenie kraju.

\section{BIBLIOGRAFIA}

BARAN D., 2016, Wizerunek Ukraińców na tamach wybranej polskiej prasy, „Państwo i Społeczeństwo", XVI, 1, s. 97-116.

BERGIER J., BERGIER B., TSOS A., 2012, Aktywność fizyczna i sedenteryjny tryb życia studentek z Ukrainy, "Człowiek i Zdrowie", 2 (VI), s. 124-137.

BIERÓWKA J., 2016, Opinie studentów ukrainskich n temat ich integracji akademickiej, „,Państwo i Społeczeństwo”, XVI, 1, s. 199213.

CBOS, 2016, Stosunek do innych narodów, Komunikat z badań, nr 53, Warszawa.

CHMiELEWSKA I., DOBROCZEK G., PUZYNKIEWICZ J., 2016, Obywatele Ukrainy pracujacy w Polsce - raport z badania, Departament Statystyki NBP Warszawa, 33 ss.

DŁUGOSZ P., 2015., Zjawisko edukacji transgranicznej na przykładzie ukraińskich studentów na Podkarpaciu, https:/ /www.ur.edu.pl /file/79298/Ukraińscy+studenci+na+Podkarpaciu-część+I. pdf.

GAWRON M., 2016, Postawy ksenofobiczne wśród studentów wybranych kierunków Krakowskiej Akademii im. Andrzeja Frycza Modrzewskiego, „Państwo i Społeczeństwo”, XVI, 1, s. 133-148.

GIERKO V., 2015, „Ukrainizacja” polskich uczelni na tle umiędzynarodowienia kształcenia na poziomie wyższym w Polsce, "Annales Universitatis Mariae Curie-Skłodowska Lublin - Polonia", $\mathrm{XL}, 2$, s. 103-119.

GUS, 2016, Szkoty wyższe i ich finanse, Warszawa, 246 ss.

GUS, 2017, Szkolnictwo wyższe w roku akademickim 2016/2017 dane wstęne, http://stat.gov.pl/obszary-tematyczne/edukacja/ edukacja/szkolnictwo-wyzsze-w-roku-akademickim-201620 17-dane-wstepne, $8,4 . \mathrm{html}$.

GÓRSKA A., 2015, Btędy studentów z Ukrainy - eliminacja i zapobieganie w grupach o zróżnicowanych możliwościach (na podstawie doświadczeń Centrum Partnerstwa Wschodniego Uniwersytetu Opolskiego), ,Acta Universitatis Lodziensis. Kształcenie Polonistyczne Cudzoziemców", 22, s. 357-370.

KORCZYŃSKA J., KAŹMIERKIEWICZ P., 2005, Regulacja migracji zarobkowej - wyzwania dla Ukrainy w kontekście polskich doświadczeń. Doświadczenia Polski po roku 1989 jako kraju wysyłającego i przyjmujacego pracowników: lekcje dla polityki Ukrainy, Warszawa.

LEŚNIAK M., 2016, Wizerunek Polski i Polaków w oczach studentów ukraińskich. Ukraińcy w oczach studentów polskich, „Państwo i Społeczeństwo", XVI, 1, s. 175-198.

ŁYsIENIA M. (red.), 2016, Cudzoziemcy w Polsce. Podręcznik dla funkcjonariuszy publicznych, Helsińska Fundacja Praw Człowieka, Warszawa, 164 ss.

Podejrzani o pobicie studentów z Ukrainy, 2017, http:/ / www. policja. $\mathrm{pl} / \mathrm{pol} /$ aktualnosci/138042,Podejrzani-o-pobicie-studentowz-Ukrainy-zatrzymani.html; 02.04.2017.

TRZCIŃSKI R., 2015, Zagraniczni studenci - czy potencjalni uczestnicy polskiego rynku pracy?, [w:] J. Konieczna-Sałamatin (red.), Imigranci o wysokich kwalifikacjach na polskim rynku pracy. Raport z badań 2014-2015, Wyd. Idee i Fundacja "Nasz Wybór", Warszawa, s. 175-210.

WOJTULEWSKI R., 2016, Akceptacja inności - spostrzeganie odmienności narodowej studentów z Ukrainy wśród studentów uczelni krakowskich, „Państwo i Społeczeństwo”, XVI, 1, s. 149-174.

http:/ / lublin.wyborcza.pl/lublin/1,48724,17036981,Studenci _o_kolegach_z_Ukrainy_Zajmuja_miejsca_Polakom.html; 02.04.2017. 